\title{
Public Libraries and School Libraries: Partnerships to Support Truth in History
}

$\mathrm{T}$

The oft-repeated admonition that those who don't know history are doomed to repeat it, has never had more meaning than in these current times. ${ }^{1}$ It has become increasingly clear that students need a solid foundation in history based on truth and clear, documented facts, unfettered by stereotypes or bias. This concept may be best supported by exposing students to collections of diverse resources and historical documents, as may be found in a combination of both public and school libraries. Using both types of library resources will more fully support efforts to develop students' information skills, research and information gathering. For North Carolina students, the development of this foundation can be supported by the efforts can public libraries and public schools work together to accomplish and enhance this goal? The answer rests with the skills and knowledge of both professional school librarians and public librarians. The specific expertise of each of these professional librarian groups can support the students, making students' study and exploration richer and more meaningful.

\section{Professional Skills of Librarians: School and Public}

The school librarian knows what is required in each grade level and subject area, and is prepared to collaborate with teachers, sharing strategies, resources, and emerging technologies. These key partners identify and provide support for diverse student information and determin the authority of sources.

The teaching of ethical research practices and accurate documentation is of primary concern at this point in the education of students. ${ }^{4}$ It is essential that school librarians play a strong role in the teaching of practices to determine not only the reliability of resources, but also the ethical use of those resources. As early as primary school, students must begin to evaluate the immense amount of information that is available today. B. J. Hamilton, in 2009, stated correctly that "We are at a critical moment in our profession, and we need to seize this moment to collaborate with our learning communities as leaders in interpreting and teaching information literacy." 5 The time to address these needs is early in the primary years. Both school and

\section{It has become increasingly clear that students need a solid foundation in history based on truth and clear, documented facts, unfettered by stereotypes or bias. 9}

of both school librarians and public librarians in sharing resources to accurate information.

In the public school system, teachers specifically address the teaching of North Carolina history in grade levels 4th and 8th, although teachers in other grade levels also contribute to this topic as it relates to their instructional content and needs. According to educator guides from the North Carolina Department of Public Instruction, the goal is to teach North Carolina history thematically, with chapters covering geography, people, and changes over time in the state's society, politics, culture, technology, demographics, and economics. ${ }^{2}$ How needs and model multiple strategies for students and other teachers to use for locating, evaluating, and ethically using information for specific purposes. They engage students in authentic learning, making use of digital tools and resources. Many students, however, need in-depth instruction on how to evaluate the contents and validity of certain digital tools and websites. ${ }^{3}$ Therefore, a critical component at this juncture of the teaching and learning process involves skills leading to the evaluation of the resources and technologies that are to be made available. School librarians must concentrate on helping students distinguish between fact and opinion, public librarians are able to design and support inquiry-based information literacy mentoring to help students inquire, think critically, and gain and create knowledge that is true and reliable.

For public librarians, the knowledge of concepts, principles, and techniques of reference and user services supporting access to relevant and accurate recorded knowledge and information to individuals of all ages and groups are integral parts of their skill set. They have practice in techniques for retrieving, evaluating, and synthesizing information from diverse sources for equally diverse users. Their knowledge related to the teaching and learning of 
concepts, processes and skills used in seeking, evaluating, and using recorded knowledge and information clearly supports collaborative partnerships with classroom teachers. ${ }^{6}$

Access to information can be further expanded when students use the public library in addition to their school library. The public library often is able to purchase materials that would not be supported in the school setting due to the specific nature of the resource or for other reasons, and yet these resources can greatly enhance the historical inquiry of those students. The reference materials and user services available in public libraries can provide access to relevant and accurate recorded knowledge and specialized information to which these students may not otherwise have access.

Former President Obama's ConnectED Initiative to broaden the impact of libraries in building powerful partnerships to improve education outcomes, has increased attention and resources for this effort. ${ }^{7}$ Together the school librarian and public librarian can provide students with a tantalizing mix of increased resources, support, and technology for inquiry-based learning.

\section{Connect Ed Challenge}

The ConnectED Library Challenge is part of an initiative for communities throughout the country to create or strengthen partnerships so that every child enrolled in school can receive a library card and have access to the books and learning resources of America's public libraries. The initiative, "designed to enrich K-12 education for every student in America," calls upon library directors to work with their mayors or county executives, school leaders, and school librarians. The project was developed with Institute for Museum \& Library Services direction and support. ${ }^{8}$
Schools and Public Libraries Supporting Each Other: Projects, Partnerships, and Tools

Before discussing current networking efforts between public and school libraries, it is important to remember prior efforts during the 1980s and 1990s that paved the way. During this productive period, North Carolina libraries, coordinated by the State Library of North Carolina and the North Carolina Department of Public Instruction, were encouraged to enter into regional cooperatives and partnerships in so-called Zones of Cooperation (ZOCs) initiatives throughout the state. These included, but were not limited to, the North Carolina Information Network (NCIN). North Carolina Wise Owl, the Wilson County Networking Project, the Neuse Regional Library's Electronic Network Project, and CLEVE-Net (Cleveland County). ${ }^{9}$

Donna Shannon's 1991 study supported the need for cooperation among school and public library systems. Shannon confirmed that school libraries were unable to meet all the information needs of their students. Shannon found that commitment and communication were two essentials in developing and sustaining cooperative relationships among school and public libraries. In order to take full advantage of resources and to optimally meet student needs, it is helpful to form interactive partnerships between school libraries and public libraries. ${ }^{10}$

Now there are a number of different initiatives, state- and nation-wide that support partnerships between public and school libraries for the benefit of students and teachers, expanding the resources that students may access. The table below includes some of the current resources available that will be of interest to North Carolina librarians, educators, and others. Further information about these and other initiatives will be shared later.

The initiatives and examples following can be replicated, or modified, to fit libraries across the state and country (see table 1).

\section{ONE Access}

Charlotte Mecklenburg Public Library (CMPL) and Charlotte-Mecklenburg Schools have a long history of working together as educational partners. This relationship was formalized in 2014 with a memorandum of understanding between the two agencies that led to the creation of the position of Educational Partnerships Manager for the CMPL. In 2015, the ONE Access (One Number Equals Access) initiative launched, allowing CMS students to use their student ID numbers as a CMPL account number, thus giving them seamless access to a world of information. Since then, more than 190,000 CMS students have interacted with CMPL using their ONE Access accounts.

This partnership was intended to provide access via CMS Student Portal to curriculum-supported content with the Library's Digital Branch; greater use of social media to promote Library resources to students, teachers, and families; and increased engagement with parents to improve understanding and use of ONE Access resources for student success, especially online classes, tutoring, ESOL support, and more. ${ }^{11}$

\section{wow Card Initiative}

Gaston County Public Library features a way to reach students with the WOW Card Initiative. This acronym for "Without Walls," is an initiative that gives every public school student in Gaston County a free digital library card to access the digital resources of the Library. WOW is enabling the access to valuable library resources for 
Table 1 Initiatives that support partnerships between public and school libraries

\begin{tabular}{|c|c|c|c|c|}
\hline Name of Resource & URL & Maintained by & Description & Especially Notice \\
\hline $\begin{array}{l}\text { NCPedia Educator } \\
\text { Resources }\end{array}$ & $\begin{array}{l}\text { https://www.ncpedia. } \\
\text { org/educator-resources }\end{array}$ & $\begin{array}{l}\text { North Carolina Gov- } \\
\text { ernment \& Heritage } \\
\text { Library at the State Li- } \\
\text { brary of North Carolina }\end{array}$ & $\begin{array}{l}\text { Page especially for K-12 } \\
\text { teachers, based on } \\
\text { North Carolina's online } \\
\text { encyclopedia }\end{array}$ & $\begin{array}{l}\text { Links to NC Curriculum, } \\
\text { Lesson Plans, and Fun } \\
\text { Activities }\end{array}$ \\
\hline $\begin{array}{l}\text { DigitalNC: North } \\
\text { Carolina's Digital } \\
\text { Heritage }\end{array}$ & $\begin{array}{l}\text { https://www.digitalnc. } \\
\text { org/ }\end{array}$ & $\begin{array}{l}\text { North Carolina Digital } \\
\text { Heritage Center, part of } \\
\text { the North Carolina Col- } \\
\text { lection at UNC Chapel } \\
\text { Hill. }\end{array}$ & $\begin{array}{l}\text { A gathering place for } \\
\text { materials contributed } \\
\text { by cultural heritage } \\
\text { institutions statewide }\end{array}$ & $\begin{array}{l}\text { Links to Yearbooks, News- } \\
\text { papers, Images, and AV on } \\
\text { the top page. }\end{array}$ \\
\hline $\begin{array}{l}\text { Education at the } \\
\text { State Archives }\end{array}$ & $\begin{array}{l}\text { http://archives.ncdcr. } \\
\text { gov/Educators }\end{array}$ & $\begin{array}{l}\text { State Archives of North } \\
\text { Carolina }\end{array}$ & $\begin{array}{l}\text { Materials especially } \\
\text { appropriate for K-12 } \\
\text { teaching and learning }\end{array}$ & $\begin{array}{l}\text { Information for Educators } \\
\text { link, http://archives.ncdcr. } \\
\text { gov/Educators/Informa- } \\
\text { tion-For-Educators, and } \\
\text { Resources and Tools link, } \\
\text { http://archives.ncdcr.gov/ } \\
\text { Educators/Resources-and- } \\
\text { Tools-for-Education, for } \\
\text { teaching suggestions and } \\
\text { lesson plans. }\end{array}$ \\
\hline $\begin{array}{l}\text { North Carolina } \\
\text { Digital Collections }\end{array}$ & http://digital.ncdcr.gov/ & $\begin{array}{l}\text { State Library of North } \\
\text { Carolina \& State } \\
\text { Archives of North } \\
\text { Carolina }\end{array}$ & $\begin{array}{l}\text { Over } 90,000 \text { historic } \\
\text { and recent photo- } \\
\text { graphs, state govern- } \\
\text { ment publications, } \\
\text { manuscripts, and other } \\
\text { resources. }\end{array}$ & $\begin{array}{l}\text { Links to Civil War, Time } \\
\text { Periods, and Places on top } \\
\text { page. }\end{array}$ \\
\hline
\end{tabular}

thousands of students to achieve educational success. An example showing how one school, Holbrook Middle, provided access to the WOW card can be found at the school website, https:// www.gaston.k12.nc.us/holbrook. ${ }^{12}$ This initiative extends the online resources of the public library to students who cannot travel to the headquarters or branches of the CMPL.

\section{N.C. Kids Digital Library}

The N.C. Kids Digital Library is a project led by the State Library of North Carolina and the N.C. Public Library Directors Association. Library users across North Carolina have free access to 16,000 e-books and other online materials for kids. This ready access provides students with materials even when schools are not in session. ${ }^{13}$

Pilot Mountain Elementary School Project

Pilot Mountain Elementary School featured an ALA-sponsored project led by award-winning librarian Amy Harpe, titled "Everybody Has a Story," to support students in recognizing people and overcoming stereotypes by comparing stories from different perspectives. ${ }^{14}$

"My hope is that students will look at people for their story and not their stereotype, think about their community in new ways, be good stewards of their culture and their history, and learn more about their town as well as the world," said Amy Harpe, the school's media specialist and the program's lead creator. This project won recognition from the American Library Association for teaching students about cultural and historic preservation both locally and globally. ${ }^{15}$ The public library, with its History Rooms and Genealogy Resources, offers a unique set of data and documents to help students learn about their own areas and cultures.
Public library patron Jennifer Dickenson discovered that "patrons can use Ancestry.com to research their family trees. I even found a copy of my grandfather's draft card from World War II. They also have digital copies of area high school yearbooks available to view. I found my mother's high school senior yearbook! One patron let the center borrow some old negatives that had belonged to her mother. It was a fascinating glimpse into the life told in pictures and how they lived back in those years. ${ }^{" 16}$

These materials may not have been available through any other source if the public library had not collected them and made them accessible to the public. So often public libraries collect, preserve, and make available unique artifacts or documents that reflect the culture of the area served. These Special Collections house the life-time collections from key members of the community, including rare or one-of-a-kind 
documents to help students learn about the unique history of their area.

It is evident that school librarians need to educate students on the available resources that may be found in the public library to support projects like "Everybody Has a Story," and many other areas of interest. Librarian Amy Harpe shared an excerpt from local public librarian Anna Nichols regarding the project: "One of the indicators of the enormous success of this program has been that students come into the public library with their parents seeking more exposure and information regarding the topics they've studied. We have answered questions, had stimulating conversational exchanges and provided copious materials on the topics of the arts, culture, language, and local persons of interest, food, town architecture, musicians, and a host of other topics that have piqued the minds of our third graders. It has been a delight to share photographs and writings from our local history room with youngsters and their families." 17

\section{Limitless Libraries}

Nashville (TN) Public Library and Metro Nashville Public Schools have partnered to create the Limitless Libraries cooperative to improve school libraries, resource sharing, and student access to learning materials. These digital resources and databases support students with a range of materials and specialized materials. ${ }^{18}$

\section{Implications for School Librarians and Public Librarian Partnerships}

In schools there is often a separation of grade levels, departments, and subject matter that prevents serious interaction. Conversely the school librarian is uniquely positioned to see all areas and has the necessary skills to lead in the teaching of digital literacies in all areas. These librarians also understand that engaging students in authentic and meaningful projects or research can support the understanding of digital literacies. It is important to identify the location of these resources and make efforts to put students in contact with them. Therefore, taking students to public libraries and using resources specifically aimed at areas of interest to the student will meet this need and provide students with opportunities to dig deeper and gain greater awareness of issues.

Since public libraries may provide a range of resources, print, or webbased, for use that students in schools have not yet encountered, introduction to those resources is needed. Public librarians who are prepared to teach students and other stakeholders can share how to use those resources. Explicit instruction will result in optimum use of resources whether digital or print.

School librarians and public librarians find huge opportunities to co-design instructional units, drawing upon the skills and strengths of each other. This supports the public libraries with stakeholder use and supports the school librarian with enhanced strengths, resources, and support. Integrating the public library resources with the school's needs through preparation, planning, and collaboration is a win-win for all. Those students, who will be adults, will learn more about the public library and what is available and will more likely grow up to be supporters of the public library. Librarians must take advantage of this and advocate for all.

The goal for both groups of librarians is to enhance students' ability to discover. Librarians will serve as facilitators for this discovery. Their role involves creating and managing meaningful learning experiences and stimulating students' thinking through the use of a wide range of resources.
When librarians encourage student use of both school libraries and public libraries we can expect to see:

- Improved access to resources unavailable in school libraries

- Increased equity in terms of student access to varied materials

- Improved academic success

- Increased student engagement and literacy

- Increased knowledge of resources to support life-long learning

- Learning is extended beyond the classroom with access to more resources

All of these points mentioned above are reasonable to expect, but the second point regarding increased access may be one of the most significant for socioeconomically disadvantaged and at-risk students. Public libraries are often described with the phrase "the great equalizer." ${ }^{19}$ Having access to the broad variety of materials unlikely to be found in the school library will "level the playing field," increase equity, and provide public school students the same advantages for research and reading that other students may have. ${ }^{20}$

\section{Conclusion}

The partnerships between public librarians and school librarians, making optimum use of resources will serve to make education deeper, more meaningful, and will facilitate life-long learning. Understanding resources and how to use them will help students through all future educational opportunities and experiences and will support their lifelong learning.

With access to multiple resources, students will be exposed to more North Carolina history, geography, politics, culture, technology, demographics, and economics. The expanded exploration by students will help them to discern truth and reality. The ability to think critically with an eye and ear to the 
facts will serve these students and the greater community well. There is no one better equipped to lead students in a deep and accurate study of North Carolina history than skilled professional librarians, school and public. Educators in schools, working collaboratively in partnership with public librarians is a "win-win" situation for all.

\section{References}

1. Good Reads, accessed Feb. 1, 2018, https://www.goodreads.com/ quotes/111024-those-who-don-tknow-history-are-doomed-to-repeatit

2. Public Schools of North Carolina, State Board of Education, Teacher's Guide, accessed Jan. 14, 2018, http:// www.dpi.state.nc.us/holocaust-council/guide/

3. American Association of School Librarians, ALA/AASL Standards for Initial Preparation of School Librarians, accessed December 15, 2017, http://www.ala.org/aasl/sites/ala.org. aasl/files/content/aasleducation/ schoollibrary/2010_standards_with_ rubrics_and_statements_1-31-11.pdf

4. Carol Brown, \& Kaye Dotson, "Writing your own history: A case study using digital primary source documents," TechTrends 51 (2007): 30-37.

5. B.J. Hamilton, “Transforming information literacy for NowGen students," Knowledge Quest, 37 (2009): 48-53.

6. Association for Library Service to Children, Competencies for Librarians Serving Children in Public Libraries, accessed Apr. 10, 2018, http://www. ala.org/alsc/edcareeers/alsccorecomps

7. Institute of Museum and Library Services, "President Obama Announces Open EBooks and Connected Library Challenge," (Apr. 30, 2015), accessed Dec. 2, 2017, https://www.imls.gov/news-events/ news-releases/president-obamaannounces-open-ebooks-and-connected-library-challenge

8. Institute of Museum and Library Services, "Connected Library Challenge," accessed Oct. 31, 2017 , https://www.imls.gov/issues/nationalinitiatives/connected-library-challenge

9. Plummer Alston Jones, Jr., "North Carolina Library Networks: A Bibliography on Library Cooperation Involving the Old North State, North Carolina Libraries Special Edition

(1992): 32-36.

10. Donna Shannon, "Cooperation Between School and Public Libraries: A Study of One North Carolina County." North Carolina Libraries 49 (Summer 1991): 67-70, in Jones, "North Carolina Library Networks," 35.

11. Christine Clark \& Martha Yesowitch, "Bringing Successful School/ Public Library Collaboration to Your Community" (research presented at the North Carolina Library Association Biennial Conference, Winston Salem, NC, Oct. 17, 2017), accessed Dec. 2, 2017, http://nclaonline.org/ conferences/2017/program/sessions/ bringing-successful-schoolpubliclibrary-collaboration-your-community

12. Holbrook Middle School, WOW Cards, accessed Jan. 14, 2018, https:// www.gaston.k12.nc.us/holbrook.

13. NC Kids, "Digital Library," accessed Feb. 22, 2018, https://nckids. overdrive.com/

14. Pilot Mountain News, "Pilot Mountain Elementary Library Recognized,' accessed Nov. 18, 2017, http://www. pilotmountainnews.com/news/4285/ award-winner

15. American Library Association, "Everybody Has a Story - 2017 Jaffarian Award Winner, "accessed Feb. 10, 2018, http://www.ala.org/tools/
programming/2017Jaffarianaward/ pilotmountain

16. Jennifer Dickenson, e-mail communication with Kaye Dotson, Aug. 30, 2017

17. Amy Harpe, e-mail communication with K. Dotson, Nov. 14, 2015.

18. Helen Adams, "Limitless Libraries: A Collaborative Partnership That Supports At-Risk Students," Knowledge Quest, accessed Jan. 21, 2018, http://knowledgequest.aasl.org/ limitless-libraries-collaborative-partnership-supports-risk-students/

19. Helen Goodman, "What's Happening to your Library?," Public Libraries News, accessed Jan. 14, 2018, http:// www.publiclibrariesnews. com/2014/07/the-great-equalizer-thepublic-libraries-elevator-pitch.html 20. American Library Association, Libraries, the Place of Opportunity, accessed Jan. 21, 2018, http://www. ala.org/advocacy/sites/ala.org. advocacy/files/content/.../libs_opportunity.pdf

Kaye Dotson

Associate Professor, Library Science, Coordinator of the MLS Program, East Carolina University

Elaine Yontz

Professor, Library Science, East Carolina University

Plummer Alston Jones, Jr. Professor, Library Science, East Carolina University 